\title{
Threatened and understudied: the lack of genetic data of endangered Brazilian plant species
}

\section{Liliana Essi'; Maria de Fátima Ribeiro Chicatte Lima" ;Leandro Gonçalves Leite ${ }^{\text {III!; }}$ Mariana Marques Wolf IV}

\begin{abstract}
A literature review of genetic studies on 3134 endangered or data deficient Brazilian plant species was performed using the Periodical Capes database, using, for each species, a combination of the binomial (without authorship) and the radical genet*. The search was only for articles, without publication year limitation. The search included relevant synonyms, based on information obtained from the National Flora Conservation Center (CNC Flora) website. Phylogenetic studies focusing on taxonomy or studies focusing on gene expression were excluded. A total of 14463 articles were retrieved with this search strategy, but only 312 fit within the scope of the search. Results show that genetic studies for plants of all threat categories are lacking, with a very low average $(0,09 \%)$ of genetic studies retrieved per species. The four threatened species with a higher number of studies are species of commercial interest. For 1931 species no article was retrieved. Given the high levels of biodiversity loss in Brazil, it is urgent to invest in the knowledge of the biology of threatened plant species, especially those which are the most neglected in genetic studies.
\end{abstract}

Keywords: Extinction; Genetic Diversity; Plant Red List

\footnotetext{
' Universidade Federal de Santa Maria, Santa Maria, Brazil. liliana.essi@ufsm.br

IV Universidade Federal de Santa Maria, Santa Maria, Brazil. mariwolf.mm@gmail.com
} 


\section{INTRODUCTION}

Brazil is considered a megadiverse country, home to an incredible variety of animals, fungi, plants, and microorganisms. According to The Brazil Flora Group (BFG, 2018), there are approximately 33885 species of plants (angiosperms, bryophytes, ferns, lycophytes, and gymnosperms), 54\% of which are endemic to the country. Thousands of these species are under threat of extinction due to unsustainable exploitation and habitat destruction or fragmentation, affecting other species connected to them. It is estimated that approximately 6,38 to $8,02 \%$ of the Brazilian green plants are threatened with extinction (BRUMMITT et al., 2015).

Extinction is a naturally occurring process, and its causes can be multiple (See section 1.1). Factors that can lead one species to extinction may not impact another species. Therefore, assessment of threat degree or the likelihood of a species becoming extinct is determined by several factors. The International Union for Conservation of Nature (IUCN) proposes a series of internationally validated criteria for identifying a species as threatened (See section 1.2). It considers fluctuations in geographic distribution over a given period or number of generations, population density, interconnection between populations, and actual or potential risks, among other factors. One of the factors considered important by the scientific community in the survival of a species is its genetic diversity (WILLOUGHBY et al., 2015). Several studies revealed that reductions in the percentages of heterozygosity in natural populations can lead to dramatic population declines and contribute to an increased probability of extinction (FRANKHAM, 1996; NEWMAN; PILSON, 1997; SPIELMAN et al., 2004; FRANKHAM, 2005).

Considering that different plant species have distinct population dynamics, with variations in life cycle, reproduction mode, and sensitivity to genetic depression, the genetic characterization of species considered endangered is fundamental to assist in conservation planning and policies, and species recovery. However, many species listed as threatened are poorly characterized. In most cases, the only studies available are species descriptions. This is a matter of concern, as ignorance of the autecology of 
a species can lead to inadequate conservation strategies. In this sense, it is necessary to question whether any species of Brazilian flora have sufficient studies to support their conservation and recovery. It is also relevant to identify the role of their genetic and evolutionary characteristics in the threat of extinction and the exogenous factors involved, especially the anthropic ones.

For this, a survey of genetic diversity studies of natural populations of Brazilian plant species known to be endangered or with notorious data deficiency was undertaken. The objective of this review is to identify gaps in knowledge of Brazilian flora, from the point of view of population genetics, with evidence regarding groups of plants that most urgently need attention and studies aimed at understanding their population dynamics. In the following sections, we briefly present some concepts that will be mentioned throughout the text, and then the methods used in the review.

\subsection{The extinction and its causes}

The extinction of a species occurs when its last member dies. However, determining the rate of occurrence of a species is challenging for researchers due to the incomplete record of species distribution and occurrence. Many threatened species are poorly known and distributed in restricted or hard-to-reach regions, making it difficult to determine their actual status (PURVIS, JONES, MACE; 2000). Some catastrophic events, such as volcanic eruptions and asteroid crashes, can instantly eliminate all individuals of a particular species. However, in slower processes, any phenomena that may cause mortality rates to exceed reproductive replacement over an extended period may also cause species extinction (SODHI, BROOK, BRADSHAW; 2009).

The probability of extinction is a function of the particular characteristics of the organism and its phylogenetic group, the particular set of causes that affect survival and/or reproductive rates, and the time scale over which these processes occur (PURVIS, JONES, MACE, 2000). The first major mass extinctions that occurred in the period between the Cambrian and the Cretaceous were mainly the result of largescale volcanism. Substantial loss of living things by volcanoes occur as a result of toxic 
metal poisoning, volcanic darkness, acid rain and ocean acidification, ozone depletion and increased UV-B radiation, and cooling and photosynthetic shutdown, each of which involves numerous events (BOND; GRASBY, 2017).

Following these historical catastrophes, the earth became more stable and balanced. However, vertebrate extinction rates of the last 200 years were significantly greater than background rates observed between 1500 and 1900. The extinction events of the last two centuries have occurred as a result of the rise of the human population and industrial development. Without human intervention, these extinctions would take millennia to occur (CEBALLOS et al., 2015). Each year since 2001, approximately 1,500 plant species are added in the IUCN Red List, and that rate is increasing (BRUMMITT et al., 2015). This number is nearly equivalent to the annual number of publications describing new plant species (more than 2000 each year average for the period 2005-2015) (BRUMMITT et al., 2015). Several plant species recently described for the first time are already threatened by extinction.

Currently, the greatest threat to the conservation of the world's biodiversity is the destruction of habitats by human exploitation through uncontrolled land use, deforestation, and hunting and fishing activities. A second major threat is the introduction of exotic species. These introduced species, mainly plants of ornamental and economic interest, cause changes in ecosystems and the biological community. Climate change is another significant threat, linked to the increase in $\mathrm{CO}_{2}$ concentration in the atmosphere (BARROSO et al., 2007). Climate warming can affect species by altering their range, behavior, morphology, species density, and reducing genetic diversity (SODHI, BROOK, BRADSHAW; 2009).

1.2 The assessment of the degree of extinction threat and IUCN categories

The IUCN degree of extinction assessment methodology includes the IUCN Red List Categories and Criteria (IUCN, 2019a; IUCN, 2019b), widely recognized as the most authoritative information source on the extinction risk of species (BRUMMITT et al., 2015). It classifies species into nine groups (Figure 1) defined by such criteria as the rate of decline, population size, degree of fragmentation, and geographic distribution area. The classification includes the following designations: least concern (low risk of 
extinction); near threatened (the species is close to being classified as vulnerable or endangered); vulnerable ( $\mathrm{VU}$, the species faces a high risk of extinction in the wild); endangered (EN, the species will likely be extinct in the near future); and critically endangered ( $C R$, the species faces extremely high risk of extinction). The final categories are extinct in the wild (species that survive only in captivity or living collections [ex. In Botanical Gardens or green houses]), and extinct (IUCN, 2019b).

Figure 1 - Structure of the IUCN Red List Categories

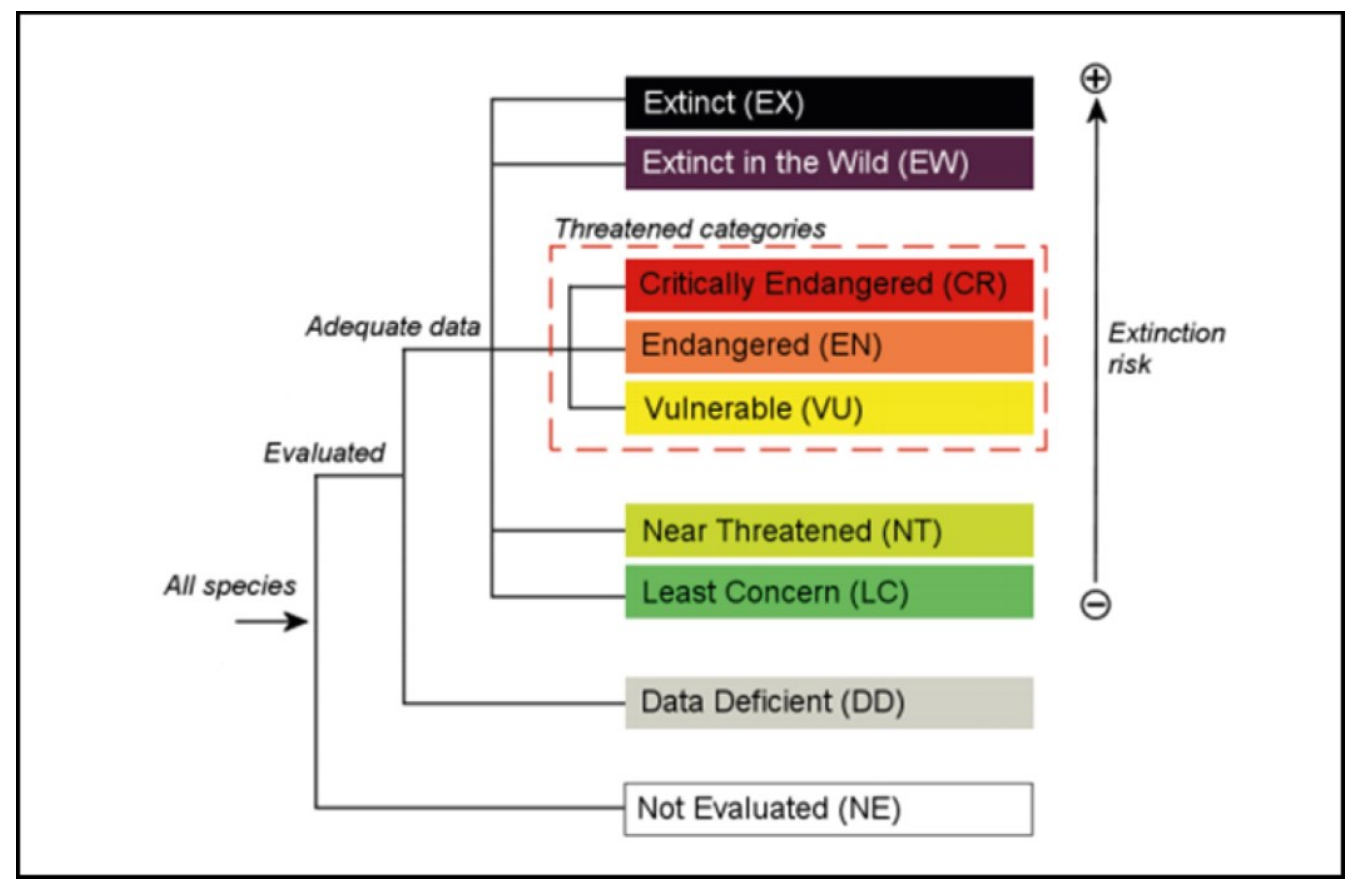

Source: IUCN, 2019b

The IUCN categories are used internationally, and the Brazilian National Flora Conservation Center website (CNC Flora) presents a Red List of Brazilian Plants according to this threat classification.

\subsection{Molecular markers and their relevance for conservancy}

Molecular markers can be used to evaluate genetic differences between two or more individuals. They may be based on gene expression products such as proteins and enzymes (e.g. isoenzymes and alloenzymes) or on differences in specific DNA sequences caused by insertion, deletion, point mutation, duplication, and 
translocation (NADEEM et al., 2018). DNA markers can be determined by various characteristics including restriction fragment length polymorphism (RFLP), amplified fragment length polymorphism (AFLP), simple sequence repeats (SSRS), singlenucleotide polymorphism (SNP) and diversity arrays technology markers (NADEEM et al., 2018). Markers are classified into two main groups: dominant and codominant. The dominant markers allow the presence or absence of determined fragments, whereas codominants allow the determination of allele frequencies in the loci (ALSAMARAI; AL-KAZAZ, 2015).

Molecular markers are extremely important for genetic studies because they have the ability to distinguish genotypes, providing information to diagnose suitable conservation areas and help identify species that are threatened with extinction (GROVER; SHARMA, 2016). Gene flow, natural population structure, and genetic polymorphism are some of the data that can be obtained through molecular DNA techniques. The information on the genetic diversity of wildlife is necessary to ascertain the genetically deteriorated populations so that better management plans can be established for their conservation (ARIF et al., 2011).

Although genetic data are recognized as extremely helpful in improving conservation strategies of threatened plant species and the use of molecular markers is a practice for the study of such species worldwide, in Brazil these studies are far from routine. The goal of this review was to present data regarding the genetic studies of Brazilian threatened plants.

\section{MATERIALS AND METHODS}

A rapid literature review was conducted in search of genetics studies of endangered Brazilian flora species. For this, the plant species listed on the Brazilian National Flora Conservation Center website (CNC Flora, http://cncflora.jbrj.gov.br/portal) as threatened (Vulnerable - VU, Endangered - EN, Critically Endangered - CR) or data deficient (DD) categories were organized into excel 
spreadsheets. For each species, a bibliographic advanced search was performed on the "Periódicos Capes" Website (http://www.periodicos.capes.gov.br), with the following search terms: "species" (binomial scientific name without authority, as a unique search term), AND, genet*. We searched for articles that meet the established filters in any part of the documents, with no limitation on year of publication. We also searched for synonyms suggested by CNC Flora. The searches were performed considering the list available on the CNC Flora Website in July 2019, and the bibliographic searches for the species were performed from August to September 2019. We analyzed the results and included articles that addressed genetic/molecular studies relevant to understanding population dynamics such as those on genetic variability, genetic diversity, genomics, or chromosome analysis. No gene expression studies or strictly taxonomic phylogenetic studies were accepted.

The data obtained were ordered by plant family and threat category. As "plants" we included only groups treated by Ruggiero et al. (2005) in superphylum Embryophyta: Anthocerotophyta, Bryophyta, Marchantiophyta, and Tracheophyta.

\section{RESULTS AND DISCUSSION}

A total of 14463 search results was obtained for the 3134 species included in the study (Table 1). The species belonged to 164 plant families. However, the total number of results is misleading because only 312 articles fulfilled the scope of the search. These articles included several different methodological approaches including DNA dominance markers (RAPD, ISSR, AFLP), DNA co-dominant markers (SSR, RFLP), protein markers (isoenzyme, alloenzyme), DNA sequencing (genomic sequencing, SNPs), genome size determination and cytogenetic approaches (chromosome counts).

When analyzing the results of genetic studies by species, we found the studies concentrated on only 145 species (Table 2), which would be an average of 2.15 studies retrieved per species studied (312/145), but only 0.09\% per total species surveyed (312 / 3134), an extremely low average. For most species only one article was 
recovered as a result, or none at all (Table 2). Four species are notable exceptions: Bertholletia excelsa Bonpl. (Lecythidaceae, 10 localized studies), Cedrela odorata L. (Meliaceae, 16 studies), Euterpe edulis Mart. (Arecaceae, 22 studies), and Swietenia macrophylla King (Meliaceae, 18 studies). Those four species are of interest in commercial extraction. Bertholletia excelsa is used in the production of Brazil nuts, Cedrela odorata and Swietenia macrophylla are wood producing species, and Euterpe edulis is used for palm heart extraction.

Table 1 - Number of Plant Families, number of species and search results ordinated by Conservation Status and number of plant families and. CR: Critically Endangered; DD: Data Deficient; EN: Endangered; VU: Vulnerable

\begin{tabular}{lcccc}
\hline $\begin{array}{l}\text { Conservation } \\
\text { Status }\end{array}$ & n. of Plant Families & n. of Species & $\begin{array}{c}\text { Total Search } \\
\text { Results }\end{array}$ & $\begin{array}{c}\text { Total Genetic } \\
\text { Studies }\end{array}$ \\
\hline CR & 87 & 527 & 903 & 22 \\
DD & 89 & 687 & 3214 & 21 \\
EN. & 123 & 1352 & 4534 & 124 \\
VU & 100 & 568 & 5812 & 145 \\
Total & $164 *$ & 3134 & $14463 * *$ & $312 * *$ \\
\hline
\end{tabular}

*The total number of plant families analyzed is not the sum of all plant families per category, as a single family may have species in several different threat categories. ${ }^{*}$ The total of results is a simple sum of results for each threat category, although a single article may include more than one species, and consequently may be duplicated.

The lack of conservation-specific genetic studies is striking for all categories analyzed, but the negative highlight is undoubtedly the lack of studies for critically endangered species (22 studies / 527 CR species).

When analyzing the results of searches by botanical family (data not shown, spreadsheet available on request), 37 botanical families were not present in any study retrieved by the research. Of these, the five families with the highest number of endangered species were Acanthaceae (36 species analyzed), Polygalaceae (19), 
Ochnaceae (14), Araliaceae (11), and Loganiaceae (10). When analyzing families by threat category, Asteraceae had no recorded study recorded of its 49 critically endangered species and only one study for the 40 species categorized as data deficient. For data deficient species in Eriocaulaceae and Fabaceae, no search results were retrieved within the scope of the study.

Regarding the methods or techniques used in the recovered articles, no categorization was performed. However, SSRs were the most widely used markers for the species investigated (e.g. ZANELLA et al., 2012; ALMEIDA et al., 2013; SCATIGNA et al., 2015, GOETZE et al., 2018). This general observation corroborates the results of Torres-Florez et al. (2017) in a review study on conservation genetics studies in Latin America, which found the use of SSRs in $33,1 \%$ of the articles.

Table 2 - Number of species with and without recovered articles by species conservation status

\begin{tabular}{lcccc}
\hline $\begin{array}{l}\text { Conservation } \\
\text { Status }\end{array}$ & $\begin{array}{c}\text { N. of } \\
\text { Speci } \\
\text { es }\end{array}$ & $\begin{array}{c}\text { N. of species } \\
\text { with at least } \\
\text { one study }\end{array}$ & $\begin{array}{c}\text { N. of species } \\
\text { without any } \\
\text { search result }\end{array}$ & $\begin{array}{c}\text { N. of species with results } \\
\text { which do not match the scope } \\
\text { of the search }\end{array}$ \\
\hline CR & 527 & 20 & 348 & 159 \\
DD & 687 & 15 & 425 & 247 \\
EN & 1352 & 73 & 848 & 431 \\
VU & 568 & 37 & 310 & 222 \\
Total & 3134 & 145 & 1931 & 1059 \\
\hline
\end{tabular}

The data presented here, although not exhaustive and susceptible to changes with modifications in search criteria or database, expose the general lack of genetic studies on Brazilian endangered plant species that may contribute to the understanding of the conservation status of natural populations. Families with threatened representatives of commercial interest (Meliaceae, Arecaceae, Orchidaceae, Apocynaceae, Araucariaceae, Lecythidaceae, and Lauraceae) had a higher number of studies, comparing with other families. A notable exception was 
Solanaceae, with a series of studies of endemic and endangered Brazilian species without effective commercial use (LORENZ-LEMKE et al., 2006; FRANCESCHINELLI ET AL., 2013; BACKES et al., 2019; JOHN et al., 2019).

Brummitt et al. (2015) estimate that one out of every five plant species evaluated in the world is threatened with extinction. The authors also point out that most plant species lack any documentation on population dynamics, and for most species, the most accessible and reliable data source is geographic distribution, and the best source for this type of data is herbariums. This reality is surely observed in relation to Brazilian species. Many of the Brazilian plant species have information only available in herbariums, and no other tracking of population dynamics in the field or with genetic or molecular biology tools.

\section{CONCLUSIONS}

There are a clear lack of genetic studies on endangered (VU, EN, CR) and data deficient (DD) plant species from Brazil that can assist with data for their population recovery and conservation. This deficiency is observed for all categories but is slightly greater for critically endangered and data deficient species. Given the high levels of biodiversity loss in the country, it is urgent to invest in the knowledge of the biology of threatened plant species, especially those without immediate commercial use, which are the most neglected with regard to genetic studies.

\section{ACKNOWLEDGMENT}

We thank CAPES for the Master's Degree fellowships of third and fourth authors. 


\section{REFERENCES}

ALMEIDA P, LÓPEZ-ROBERTS M, VIGNA B, SOUZA A, GÓES-NETO A, VAN DEN BERG C. Microsatellite markers for the endangered orchids Cattleya labiata Lindl. and C. warneri T. Moore (Orchidaceae). Conservation Genetics Resources. 2013; 5(3): 791 794.

AL-SAMARAI FR, AL-KAZAZ AA. Molecular Markers: an Introduction and Applications. European Journal of Molecular Biotechnology. 2015; 9(3): 118-130.

ARIF IA, KHAN HA, BAHKALI AH, AL HOMAIDAN AA, AL FARHAN AH, AL SADOON M, SHOBRAK M. DNA marker technology for wildlife conservation. Saudi J. Biol.. 2011;18(3): 219-225.

BACKES A, MÄDER G, TURCHETTO C, SEGATTO AL, FREGONEZI JN, BONATTO SL, FREITAS LB. How diverse can rare species be on the margins of genera distribution? AoB PLANTS. 2019; 11(4): plz037. https://doi.org/10.1093/aobpla/plz037

BARROSO CM, KLEIN GN, DE BARROS IB, FRANKE LB, DELWING AB. Considerações sobre a propagação e o uso ornamental de plantas raras ou ameaçadas de extinção no Rio Grande do Sul, Brasil. Ornamental Horticulture, 2007; 13 (2).

BFG (The Brazil Flora Group). Brazilian Flora 2020: Innovation and collaboration to meet Target 1 of the Global Strategy for Plant Conservation (GSPC). Rodriguésia. 2018; 69(4): 1513-1527. DOI: 10.1590/2175-7860201869402

BOND DPG; GRASBY SE. On the causes of mass extinctions. Palaeogeography, Palaeoclimatology, Palaeoecology, 2017; 478: 3-29.

BRUMMITT NA, BACHMAN SP, GRIFFITHS-LEE J, LUTZ M, MOAT JM et al. Green Plants in the Red: a baseline global assessment for the IUCN sampled red list index for plants. PLOS One. 2015; DOI: 10.1371/journal.pone.0135152.

CEBALLOS, G, EHRLICH PR, BARNOSKY AD, GARCIA A, PRINGLE RM, PALMER TM. Accelerated modern human-induced species losses: Entering the sixth mass extinction. Science advances, 2015; 1(5): p. e1400253.

FRANCESCHINELLI EV, STEHMANN JR, MELO-SILVA C, MESQUITA NETO, JN. Preliminary study on genetic diversity of endemic and threatened species of Petunia (Solanaceae). Darwiniana. 2013; 1(2): 220-226.

FRANKHAM, R. Genetics and extinction. Biological Conservation. 2005; 126 (2): 131 140.

FRANKHAM, R. Relationship of Genetic Variation to Population Size in Wildlife. Conservation Biology. 1996; 10: 1500-1508. 
GOETZE M, CAPRA F, BÜTTOW M, ZANELLA C, BERED F. High genetic diversity and demographic stability in Aechmea kertesziae (Bromeliaceae), a species of sandy coastal plains (restinga habitat) in southern Brazil. Botanical Journal of the Linnean Society. 2018; 186(3): 374-388.

GROVER A, SHARMA PC. Development and use of molecular markers: past and present. Critical reviews in biotechnology. 2016;36(2): 290-302.

IUCN, 2019a. The IUCN Red List of Threatened Species. Version 2019-2. https://www.iucnredlist.org. Accessed 30 September 2019.

IUCN, 2019b. Guidelines for Using the IUCN Red List Categories and Criteria. Version 14. Prepared by the Standards and Petitions Subcommittee. http://cmsdocs.s3.amazonaws.com/RedListGuidelines.pdf. Downloaded 30 September 2019.

JOHN AL W, MÄDER G, FREGONEZI JN, FREITAS LB. Genetic diversity and population structure of naturally rare Calibrachoa species with small distribution in southern Brazil. Genetics and Molecular Biology. 2019; 42(1): 108-119.

LORENZ-LEMKE AP, MÄDER G, MUSCHNER VC, STEHMANN JR, BONATTO SL, SALZANO FM, FREITAS LB. Diversity and natural hybridization in a highly endemic species of Petunia (Solanaceae): a molecular and ecological analysis. Molecular Ecology. 2006; 15(14): 4487-4497.

NADEEM MA, NAWAZ MA, SHAHID MQ, DOĞAN Y, COMERTPAY G, YILDIZ M, HATIPOĞLU R, ALSALEH FA, LABHANE N, ÖZKAN H, CHUNG G, BALOCH FS. DNA molecular markers in plant breeding: current status and recent advancements in genomic selection and genome editing. Biotechnology \& Biotechnological Equipment. 2018; 32(2): 261-285.

NEWMAN D, PILSON D. Increased Probability of Extinction Due to Decreased Genetic Effective Population Size: Experimental Populations of Clarkia pulchella. Evolution. 1997; 51(2): 354-362.

PURVIS A, JONES, KE, MACE GM. Extinction. BioEssays. 2000; 22(12): 1123-1133.

RUGGIERO MA, GORDON DP, ORRELL TM, BAILLY N, BOURGOIN T, BRUSCA RC, CAVALIER-SMITH T, GUIRY MD, KIRK PM. A higher level classification of all living organisms. PLOS One. 2015;1-60. DOI:10.1371/journal.pone.0119248.

SCATIGNA AV, OLIVEIRA FA, MANTELLO CC, FRANCISCO PM, SOUZA AP, SIMÕES AO. Microsatellite markers for studies with the carnivorous plant Philcoxia minensis (Plantaginaceae. Applications in Plant Sciences. 2015; 3(8). DOI: 10.3732/apps. 1500035. 
SODHI NS, BROOK BW, BRADSHAW, CJA. Causes and consequences of species extinctions. The Princeton guide to ecology, 2009; 1: 514-520.

SPIELMAN D, BROOK BW, FRANKHAM R. Most species are not driven to extinction before genetic factors impact them. PNAS. 2004; 101 (42): 15261-15264. https://doi.org/10.1073/pnas.0403809101.

TORRES-FLOREZ JP, JOHNSON W.E., NERY MF, EIZIRIK E, OLIVEIRA-MIRANDA, MA, GALETTI JR PM. The coming of age of conservation genetics in Latin America: what has been achieved and what needs to be done. Genetics Genetics. 2017; DOI 10.1007/s10592-017-1006-y.

WILLOUGHBY JR, SUNDARAM M, WIJAYAWARDENA BK, KIMBLE SJA, JI Y, FERNANDEZ NB, ANTONIDES JD, LAMB MC, MARRA MJ, DEWOODY JA. The reduction of genetic diversity in threatened vertebrates and new recommendations regarding IUCN conservation rankings. Biological Conservation. 2015; 191: 495-503.

ZANELLA CM, JANKE A, PAGGI GM, GOETZE M,REIS MS, BERED F. Microsatellites in the Endangered Species Dyckia distachya (Bromeliaceae) and Cross-Amplification in Other Bromeliads. International Journal of Molecular Sciences. 2012; 13(12): 1585915866. 